\title{
PENERAPAN METODE BEHAVIORAL ARCHITECTURE DALAM PERANCANGAN RUANG KOMUNAL - INFORMAL
}

\author{
Ignatius Kevin Sutjiadi ${ }^{1)}$, Sutarki Sutisna ${ }^{2)}$ \\ 1)Program Studi S1 Arsitektur, Fakultas Teknik, Universitas Tarumanagara, ignatiuskevin01@gmail.com \\ 2)Program Studi S1 Arsitektur, Fakultas Teknik, Universitas Tarumanagara, tarkisutisna@gmail.com
}

\begin{abstract}
Abstrak
Kehidupan di kawasan perkotaan dengan berbagai macam tekanan, baik dari tempat tinggal, tempat kerja maupun sekolah, membuat para masyarakat memiliki tingkat kejenuhan yang lebih tinggi. Masyarakat ini membutuhkan sebuah ruang perantara antara tempat tinggal ( first place ) dan juga tempat kerja/ belajar ( second place) yang berupa sebuah Third Place. Third Place ini sendiri memiliki fungsi penting bagi masyarakat untuk menjadi sebuah tempat atau ruang di mana mereka bisa bebas menjadi diri mereka sendiri, menyalurkan minat bakat, sekaligus juga bersosialisai dengan sesama mereka setelah melakukan kesibukan masing-masing. Maka dari itu, muncul sebuah kebutuhan dari bentuk arsitektur yang berupa third place dengan Interaction untuk memfasilitasi kegiatan para pengguna untuk bisa bercengkerama atau berbicara dengan satu sama lain, lalu Creative dan juga Expressive yang mana bertujuan untuk menyalurkan ide, kreativitas, serta minat bakat yang bisa digunakan untuk mengembangkan kemampuan dari pengguna. Kelurahan Semanan, Kalideres, merupakan sebuah lokasi dimana terdapat banyak aktivitas seperti area permukiman, area perbelanjaan dan juga kawasan industri. Industri disini berupa pabrik-pabrik serta komplek pergudangan yang mana memiliki banyak pegawai yang bekerja disana. Dari keadaan dan potensi kawasan sekitar menjadikan Ruang KomunalInformal ini menjadi sebuah third place yang strategis serta bisa mewadahi kebutuhan dari aktivitas masyarakat Kelurahan Semanan dan sekitarnya.
\end{abstract}

\section{Kata kunci : Creative; Expressive; Interaction}

\begin{abstract}
Life in an urban area with a wide range of pressures, both from home, workplace and school, makes the community have a higher level of saturation. This community needs a space between the first place and also the workplace/study (second place) which is a Third Place. Third Place itself has an important function for the community to become a place or space where they can freely become themselves, channeling the interest of talent, as well as socializing with their fellow people after doing their busy activities. Therefore, there is a need of the form of architecture that is a third place with Interaction to facilitate the activities of the users to be able to chat or talk to each other, then Creative and also Expressive which aims to distribute ideas, creativity, and interest of talent that can be used to develop the capabilities of the users. Semanan, Kalideres, is a location where there are many activities such as residential area, shopping area and also industrial area. The industry is a factory and a warehouse complex which has many employees who work there. From the circumstances and potential of the surrounding area make this communal-Informal space become a third place strategic and can provide the needs of community activities Semanan and surrounding areas.
\end{abstract}

Keywords : Creative; Expressive; Interaction 


\section{PENDAHULUAN}

Jakarta merupakan sebuah kota yang dapat dikategorikan sebagai kota metropolitan, yang dapat diartikan bahwa kota tersebut terbentuk dari beberapa kota atau daerah administratif yang bergabung dan menjadi sebuah kota. Jakarta sebagai sebuah kota merupakan area bagi masyarakat untuk hidup dan tinggal, yang mana terdapat berbagai macam aktivitas di dalamnya. Dapat disebutkan contoh seperti kehidupan sehari-hari seorang karyawan ataupun buruh pabrik, dimana mereka melakukan kegiatannya setiap hari.

Dari contoh aktivitas tersebut, kegiatan tersebut merupakan sebuah rutinitas yang menciptakan kejenuhan bagi masyarakat tersebut. Aktivitas yang kerap dilakukan hampir setiap hari seperti peralihan antara dari rumah menuju ke tempat bekerja dan juga sebaliknya. Tak bisa disangkal, dari keseharian yang hectic tersebut manusia juga membutuhkan kegiatan yang mampu untuk merelaksasikan pikiran dan tubuhnya. Seperti berinteraksi dengan sesamanya, bercengkrama satu sama lain. Interaksi secara sosial ini secara tidak langsung dapat mengobati kejenuhan yang dialami.

Dari keadaan seperti itu, memunculkan kebutuhan yakni sebuah ruang transisi, tempat singgah antara rumah dan juga tempat bekerja yang berupa Third Place disini merupakan sebuah tempat dimana masyarakat bisa bercengkrama melepas penat, saling bertukar informasi/ kabar, menikmati jajanan retail. Lokasi Third Place ini optimalnya berada didekat area kerja sehingga para pengguna dapat mampir terlebih dahulu sebelum pulang untuk sekadar bercengkrama ataupun melakukan hal lainnya.

Open Architecture merupakan sebuah konsep yang menekankan pada sifat openness, yaitu keterbukaan, sehingga dapat diartikan sebagai arsitektur yang terbuka, atau dikatakan bisa menerima berbagai macam program di dalamnya. Open Architecture for the Third Place merupakan konsep third place yang memiliki program utama yang didukung oleh programprogram lain yang tidak jarang saling berkontradiksi. Kontradiksi ini adalah merupakan bentuk keterbukaan dari arsitektur tersebut, di mana manusia bisa merubah sebuah space menjadi place. Konsep ini akan menjadi sangat cocok untuk mendesain third place untuk masyarakat kota karena dapat menaungi kebutuhan program mereka yang berbeda-beda. Third place diperlukan di dalam bagi masyarakat kota sebagai wadah untuk menyalurkan minat, bakat, kreativitas dan juga sebagai ruang publik tempat beraktivitas, bersosialisasi dan membangun komunitas yang berkelanjutan. Oleh karena itu, merencanakan third place dengan konsep open architecture menjadi hal yang berguna bagi masyarakat kota.

\section{Rumusan Permasalahan}

Menunjukan bagaimana dalam menerapkan metode behavioral architecture dalam perancangan ruang komunal - informal, serta menunjukan peranan arsitektur dalam membantu untuk mewadahi interaksi masyarakat. Juga untuk menunjukan mengenai penerapan tema open architecture dalam merancang sebuah thirdplace bagi masyarakat yang juga diharapkan dapat memenuhi kebutuhan masyarakat sekitar tapak proyek lewat desain dari program third place ini.

\section{Tujuan}

Bertujuan untuk merancang perwujudan arsitektur dengan konsep Third Place yang berguna untuk mewadahi sebagai tempat untuk masyarakat bisa saling berinteraksi. Dengan adanya teori dari Open Architecture yang bisa diterapkan dalam proses merancang sebuah Third Place bagi masyarakat. Program - program yang diajukan dalam proyek memiliki tujuan agar bisa dan mampu memenuhi kebutuhan dari masyarakat sekitar, baik dari sisi interaksi sosial maupun dari sisi pengembangan bakat dan juga perekonomian. 


\section{KAJIAN LITERATUR}

Third Place adalah sebuah istilah yang diusung oleh seorang sosiolog, Ray Oldenburg. Yang mengacu kepada tempat di mana orang menghabiskan waktu di antara tempat tinggal (first place) dan tempat kerja (second place). Di tempat ini, orang-orang dapat bertukar pikiran, menikmati waktu, berinteraksi, dan membangun relasi satu sama lain. Third Place adalah tempat publik yang netral yang dapat digunakan untuk berbagai aktivitas dan dapat digunakan oleh siapa saja. Third Place di Inggris adalah pubs, di Prancis, terdapat café-café sebagai third place. Di Amerika, third place bisa berada di kantor pos, barbershop, ataupun kedai minuman.

\section{Karakteristik Third Place}

a. Third place adalah tempat yang netral. Artinya, semua orang bisa datang dan pergi kapan saja.

b. Third place adalah tempat yang penuh dengan kesetaraan. Perbedaan status tidak dipermasalahkan di tempat tersebut. Tidak ada yang derajatnya lebih tinggi atau lebih rendah, tidak ada yang menjadi tuan rumah atau tamu.

c. Mengobrol dan berinteraksi adalah kegiatan utama di third place.

d. Aksesibilitas sangat penting bagi third place. Sebuah third place haruslah mudah diakses dari mana saja dan memiliki jam operasional yang jauh melebihi jam kantor, karena kebanyakan pengguna akan datang ke third place setelah selesai bekerja.

e. Third place memiliki pengunjung tetap. Walaupun memiliki pengunjung tetap, orang baru yang ingin bergabung akan tetap diterima dengan mudah di komunitas third place.

f. Third place adalah tempat di mana orang-orang bisa bebas berekspresi tanpa berpura-pura. Di third place, kita bisa menjadi diri sendiri.

g. Suasana utama di third place haruslah ceria dan menyenangkan. Third place haruslah penuh dengan canda tawa.

\section{Definisi Ruang Komunal}

Ruang komunal (berasal dari kata communal yang berarti berhubungan dengan umum) merupakan ruang yang menampung kegiatan sosial dan digunakan untuk seluruh masyarakat atau komunitas (Wijayanti, 2000). Menurut Lang (1987), ruang komunal memberikan kesempatan kepada orang untuk bertemu, tetapi untuk menjadikan hal itu diperlukan beberapa katalisator. Katalisator yang dapat diartikan sebagai individu yang membawa orang secara bersama-sama dalam sebuah aktifitas, diskusi atau topik umum. Sebuah ruang terbuka publik akan menarik orang jika terdapat aktifitas dan orang dapat menyaksikannya.

\section{Jenis Ruang Komunal}

Berdasarkan pengertian ruang komunal dari Wijayanti yang mengatakan ruang komunal adalah ruang yang menampung seluruh kegiatan dari masyarakat/ komunitas, dapat diartikan bahwa sifat ruang tersebut sebagai ruang publik. Sebagian ahli mengatakan ruang publik adalah ruang terbuka, namun Hakim (1987) dan Studyanto (2009) menjelaskan bahwa ruang publik terbagi menjadi dua jenis:

a. Ruang publik tertutup, yaitu ruang publik yang terdapat di dalam suatu bangunan.

b. Ruang publik terbuka, yaitu ruang publik yang berada di luar bangunan yang sering juga disebut ruang terbuka (open space).

\section{Jenis Kegiatan pada Ruang Komunal}

Menurut Darmiwati (2000), dalam Jurnal Dimensi Teknik Arsitektur mengenai pengertian ruang komunal, diketahui bahwa fungsi ruang komunal sebagai wadah interaksi sosial, yang menampung kebutuhan akan tempat untuk bertemu, berinteraksi, melakukan aktifitas bersama. 
Kemudian dari fungsi ruang komunal tersebut, dirumuskan tiga kelompok jenis kegiatan yang dapat diwadahi oleh ruang komunal sebagai berikut:

a. Berkumpul dan berinteraksi

b. Jenis kegiatan yang termasuk dalam kelompok ini misalnya bertegur sapa, berbincang/ngobrol, dan lain-lain.

c. Bermain dan berolahraga

d. Jenis kegiatan yang termasuk dalam kelompok ini misalnya bermain kartu, berbagai permainan anak - anak, catur, senam, sarana rekreasi, dan lainnya.

e. Melaksanakan acara/ hajatan

f. Adapun jenis kegiatan yang termasuk dalam kelompok ini misalnya arisan, ulang tahun, rapat penghuni, dan lain-lain.

Proyek ini merupakan sebuah Third Place yang menekankan pada interaksi, kretivitas dan juga ekspresif dimana proyek ini bisa menjadi sebuat tempat yang bisa mengumpulkan para orangorang untuk saling berinteraksi dan juga menyediakan tempat bagi mereka untuk saling menjalin relasi dan juga menciptakan sebuah komunitas baru dari bidangnya masing-masing.

\section{METODE}

Metode yang digunakan dalam proyek ini adalah metode behavioral architecture, yakni arsitektur yang berwawasan perilaku yang bertujuan untuk menciptakan ruang dan suasana yang sesuai dengan perilaku manusia, lingkungan, dan budaya masyarakatnya (Heimsath, 1998). Berdasarkan dari metode behavioral architecture, jika kita mengetahui perilaku manusia di suatu lingkungan, maka kita dapat mengetahui apa kebutuhan manusia di lingkungan tersebut. Oleh karena itu, untuk memenuhi kebutuhan, harus mengetahui dan mempelajari behavior dari manusia di lingkungan tersebut. Penerapan metode kedalam proyek berupa Transprogramming, metode ini memiliki fungsi mengkombinasikan antara dua program yang sifat dan konfigurasi spasialnya berbeda. Dari dua program yang di kombinasikan ini menghasilkan sebuah objek yang baru berdasarkan dari antar dua program yang saling bersimpangan. Combination, metode ini memiliki fungsi untuk menggabungkan beberapa variable/element yang berdiri sendiri menjadi sebuah hal yang baru. Dalam proyek ini, kedua metode tersebut dipilih dan diterapkan dengan contoh program, adanya zona komersil ( retail ) yang di combine dengan zona edukasi, yang mana edukasi disini berupa pelatihan dalam bidang entrepreneurship.

\section{DISKUSI DAN HASIL}

Informal - Communal Space, merupakan sebuah ruang komunal yang terbuka bagi publik umum, terutama bagi para kaum buruh serta karyawan, maupun masyarakat sekitarnya. Mereka membutuhkan ruang antara ini, yang bukan merupakan sebuah tempat tinggal dan juga bukan sebuah tempat kerja. Namun, sebuah ruang dimana mereka bisa secara bebas berekspresi, berinteraksi, serta berkreasi juga tanpa adanya "boundary" atau batasan antar sesama mereka di dalam lokasi proyek. Semua ini terjadi di luar kegiatan rutinitas yang mereka lakukan sehari hari.

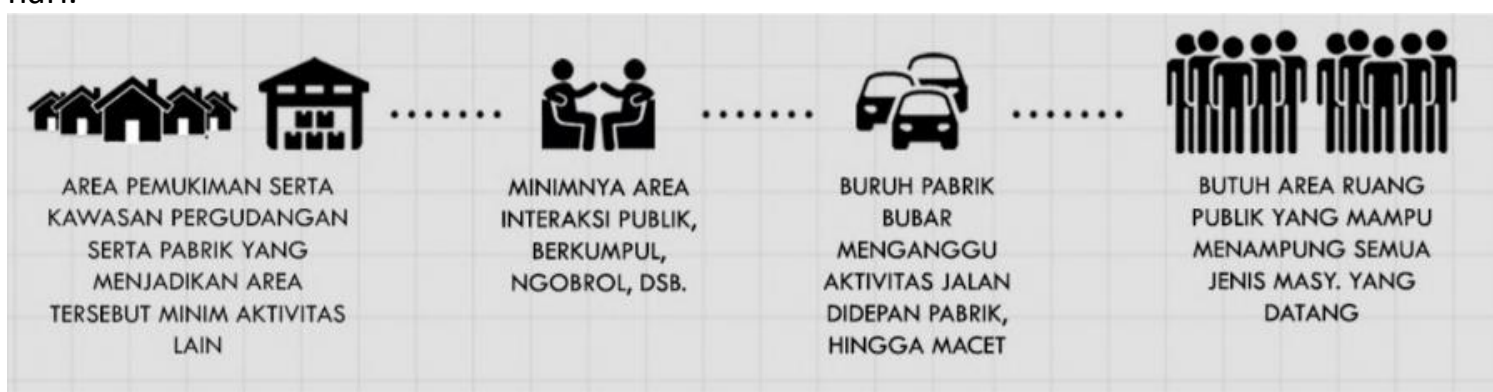

Gambar 1. Konsep Latar Belakang

Sumber: Penulis, 2020 
Informal-Communal Space, adalah sebuah ruang antara yang bisa mewadahi kebutuhan penggunanya untuk bisa berinteraksi, berkreasi antar sesamanya dan juga menyediakan fasilitas untuk meningkatkan kemampuan dan kreatifitas mereka. Selain itu, Informal-Communal Space juga menyediakan fasilitas bagi para penggunanya untuk sekedar bersantai dan melepas penat di area taman terbuka hijau, ditambah juga dengan adanya fasilitas jajanan dan retail yang bisa dinikmati. Informal-Communal Space, merupakan sebuah area kegiatan publik yang diajukan dari tiga aspek: Interaction, Creative, Expressive.

\section{Interaction}

Interaksi disini ditumbuhkan dengan cara memfasilitasi kegiatan untuk bercengkerama untuk berbicara satu sama lain, saling bertukar info maupun hanya sekadar ingin bersosialisasi. Kegiatan ini akan terbentuk dan menjadi sebuah Interaction Zone dimana para pengguna dapat saling berinteraksi antara satu sama lain. Zona interaksi disini dapat dibentuk dalam rupa taman kecil ataupun pada area jajanan retail.

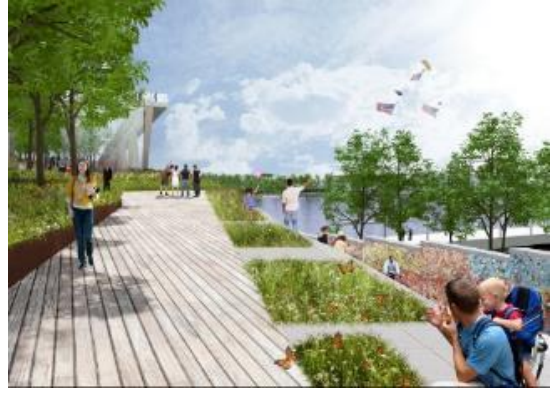

Gambar 2. Riverbank Park Sumber: dezeen.com

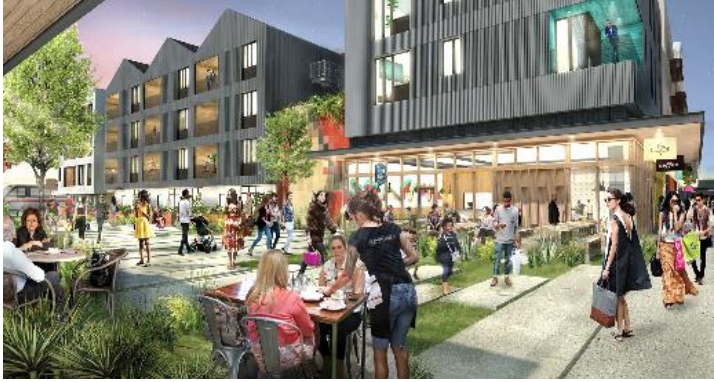

Gambar 3. Retail Area Sumber: https://www.endeavorre.com/properties/saltillo-retail/

\section{Creative}

Mendukung serta menyediakan fasilitas - fasilitas yang mewadahi bagi para warga sekitar yang bekerja sebagai pedagang ataupun yang ingin menjadi seorang entrepreneur dengan menjadi ruang atau area kerja baru bisnis - bisnis yang akan tumbuh. Dan dengan ini bisa menambah status serta taraf ekonomi masyarakat sekitar.

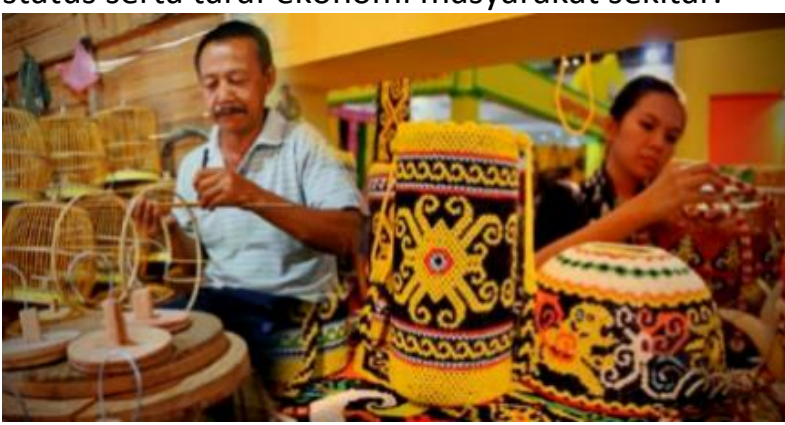

Gambar 4. Ilustrasi UMKM

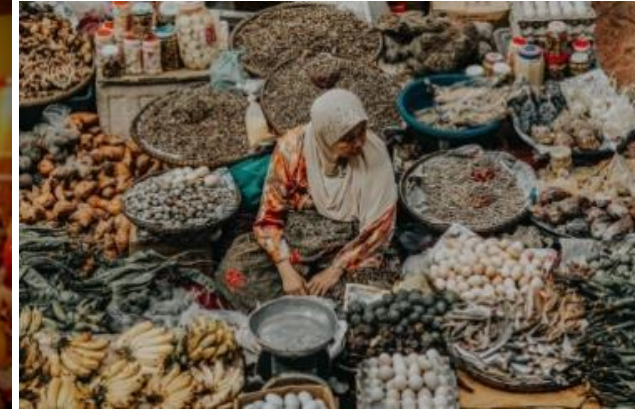

Gambar 5. Ilustrasi pedagang

Sumber: google.com

\section{Expressive}

Menyediakan fasilitas bagi para muda-mudi disekitar tapak untuk mengembangkan minat dan bakat mereka. Dengan cara disediakan berbagai macam sarana untuk berekspresi baik dalam minat, bakat, maupun hobby mereka. Dikarenakan jika dilihat pada eksisting banyak para orang muda menghabiskan waktunya hanya untuk memancing dipinggir sungai dan kegiatan yang kurang bermanfaat lainnya. 


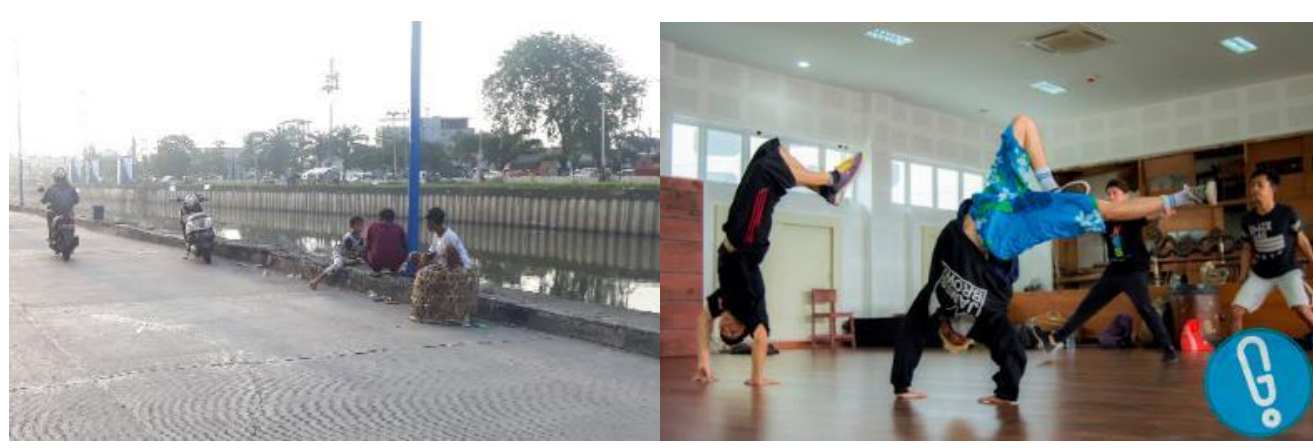

Gambar 6. Memancing di Kali Sumber: Dok. Pribadi, 2019
Gambar 7. Pengembangan Hobby

Sumber: http://www.genmuda.com/

Lokasi tapak terletak di kawasan Kelurahan Semanan, Kalideres, Jakarta Barat. Lokasi ini dipilih karena terdapat berbagai aktivitas seperti area permukiman, area pusat perbelanjaan, juga terdapat kawasan industri, serta terhubung dengan fasilitas transportasi yang memadai. Hal ini dapat mendukung sebagai kriteria dari Third Place. Keadaan eksisting yang terletak di Kawasan Kelurahan Semanan ini memiliki keadaan yang tidak terawat dan cenderung kumuh. Ditambahnya lagi dengan keadaan pasar yang cenderung tidak tertata secara rapi, serta titik lokasi berhenti angkutan umum yang acak sehingga kerap menimbulkan kemacetan. Dikarenakan dari beberapa hal-hal inilah menjadi aspek pendukung dilakukan perbaikan dan perkembangan terhadap tapak dan kawasan sekitarnya.

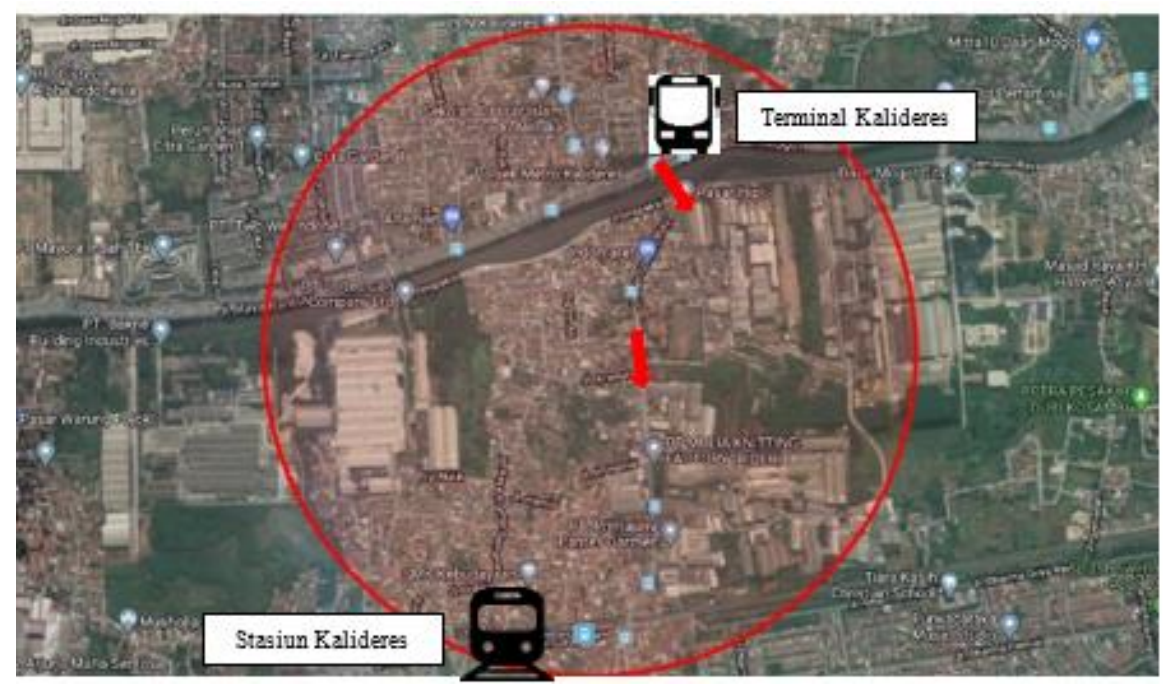

Gambar 8. Peta Jangkauan Wilayah Tapak Sumber: Google Maps

Pemilihan tapak di lokasi terpilih merupakan hasil dari pertimbangan berbagai aspek, antara lain sebagai berikut :

a. Fungsi utama tapak yang mendukung dan sesuai untuk proyek.

b. Akses ke tapak yang mudah karena terdapat banyak opsi yang mendukung yakni berupa sistem transportasi, baik berupa transjakarta, angkot, maupun kereta untuk menuju tapak yang terdapat di kawasan sekitar tapak.

c. Dalam lingkup radius $500 \mathrm{~m}$ - $1 \mathrm{~km}$ dari tapak, terdapat kawasan pabrik tekstil, makanan, kawasan perkantoran, terminal bis, stasiun kereta, serta kawasan permukiman, yang mana menjadi lokasi yang strategis bagi proyek. 


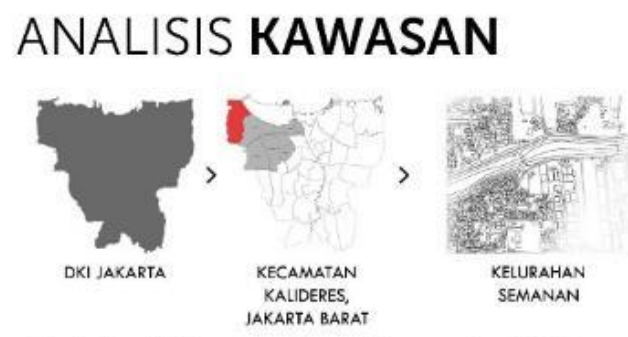

Lokasi : JI. Semanan Raya, Kecamatan Kalideres, Kelurahan Semanan - Jakarta Barat
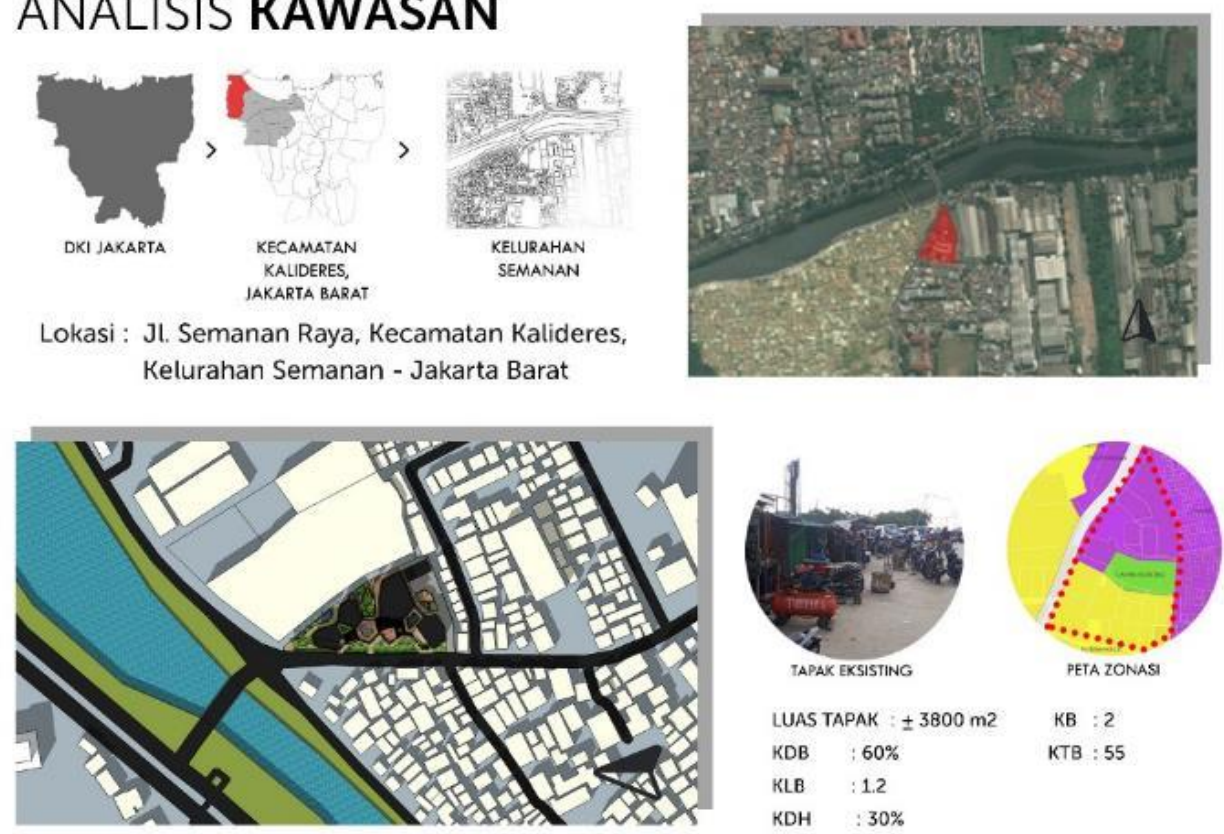

\section{SURROUNDING DEVELOPMENT}

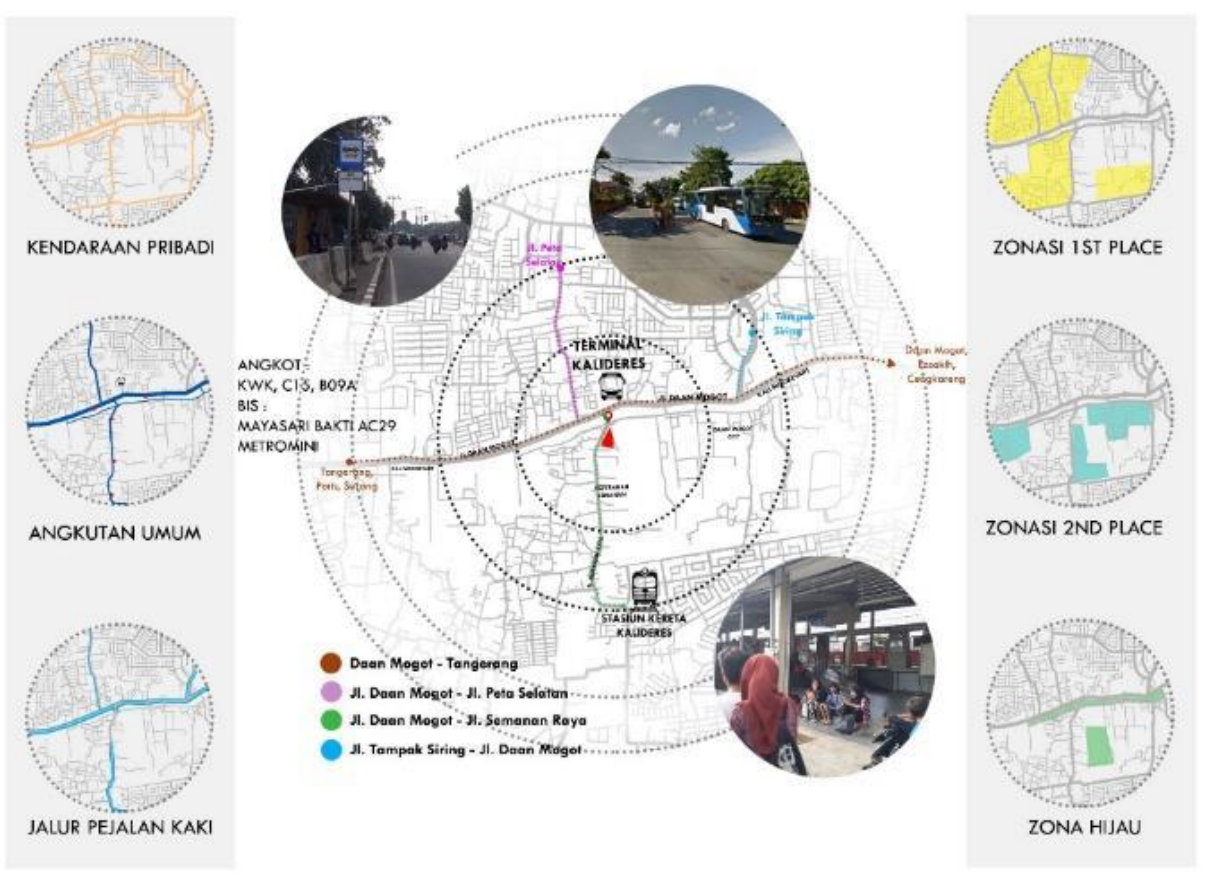

Gambar 9. Analisa Kawasan

Sumber: Penulis, 2020

Informal-Communal Space dibagi menjadi beberapa zona, juga memiliki 3 program utama yaitu Interaction (Ruang Interaksi), Creative (Komersial), Expressive (Zona Kembang Bakat) lalu selain program utama, proyek ini juga dilengkapi dengan program pendukung yakni zona servis dan juga pengelola. 


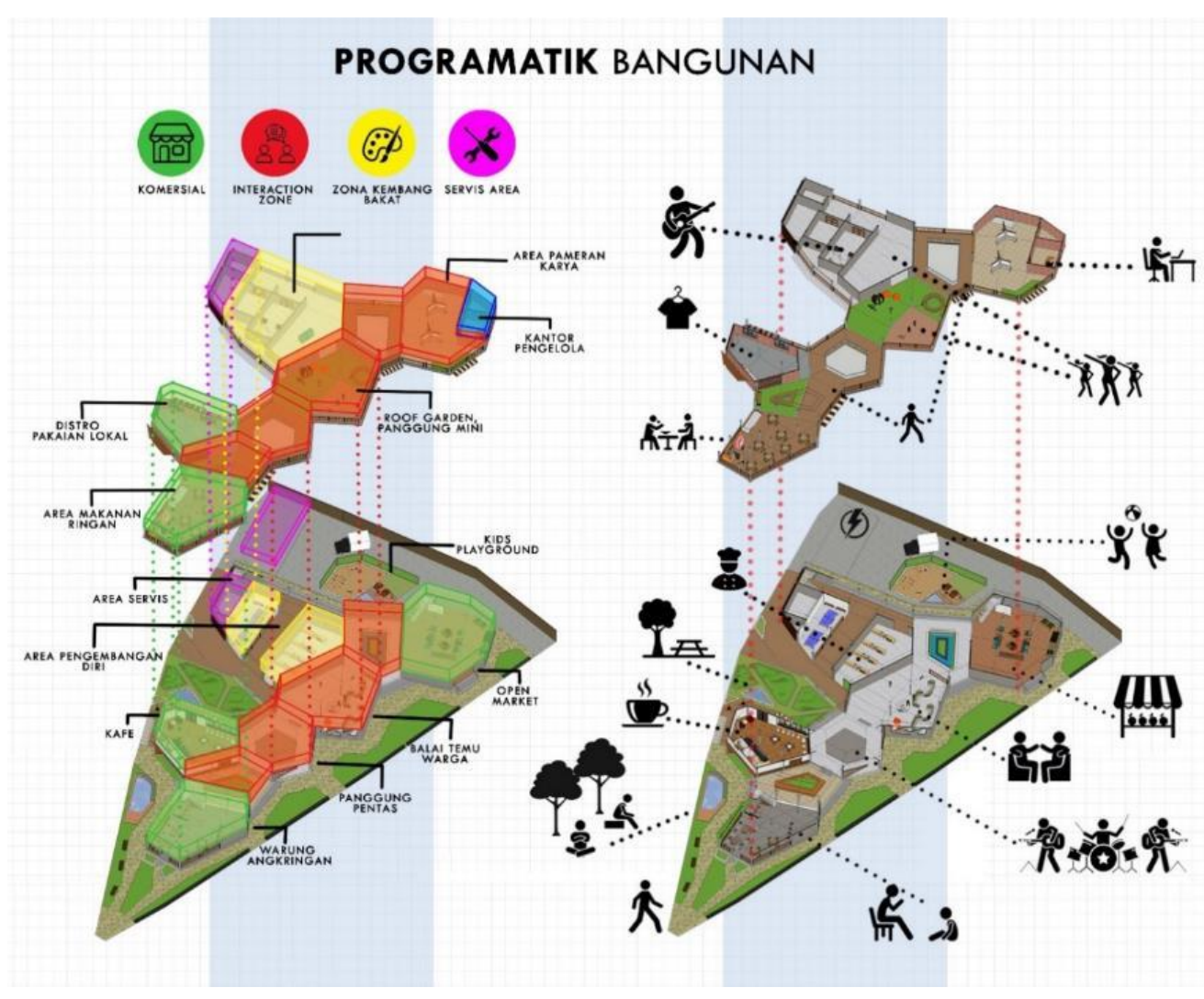

Gambar 10. Programatik + Zoning Bangunan Sumber: Penulis, 2020

\section{TRANSFORMASI MASSA}

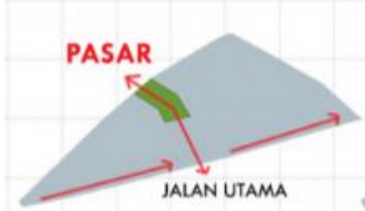

TAPAK DIOLAH BERDASARKAN ORIENTAS

SEKITAR, DIUTAMAKAN

DISINI ADALAH AKSES

YANG MUDAH BAG

PEJALAN KAKI

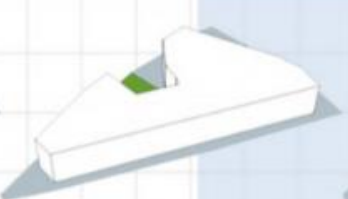

\begin{abstract}
BENTUK DASAR MASSA DIBENTUK MENYESUAIKAN BENTUK TAPAK, TAPI TETAP MENGIKUTI ORIENTASI
\end{abstract}

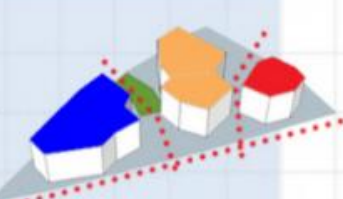

PEMBAGIAN MASSA DITATA SESUAI DENGAN PROGRAM YANG DIAJUKAN. SERTA DENGAN FUNGSINYA MASING-MASING

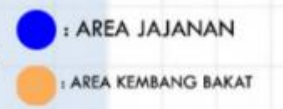

: PASAR TERBUKA
PERMAINAN TINGGI BANGUNAN

MENCIPTAKAN KESAN

DINAMIS, DAN TIDAK

MENCIPTAKAN KESAN YANG KONTRAS DENGAN SEKELILINGNYA

Gambar 11. Transformasi Massa

Sumber: Penulis, 2020

\section{Output Hasil Desain}

Hasil output pada rancangan desain bertujuan untuk membantu memenuhi kebutuhan ruang serta sarana berkumpul bagi masyarakat di kawasan Semanan, antara lain: 
a. Area Angkringan

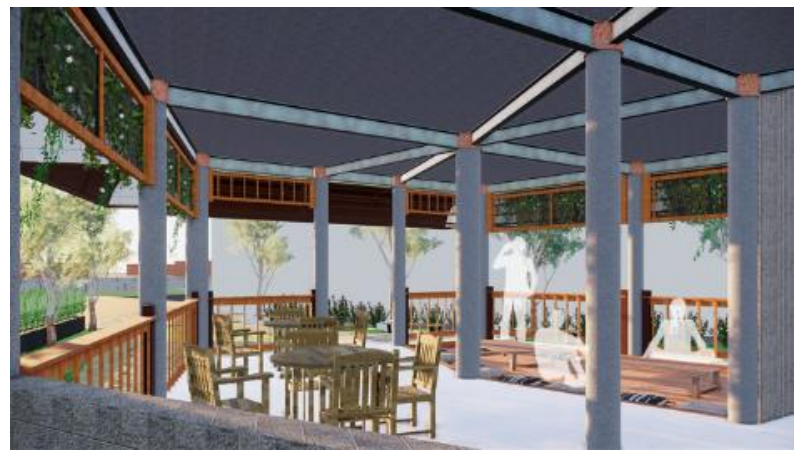

Gambar 12. Area Angkringan

Sumber: Penulis, 2020

Merupakan sebuah tempat makanan, yang diperuntukan terutama bagi para karyawan pabrik untuk kemudahan dalam mencari makan, serta untuk saling berinteraksi.

b. Area Panggung Pentas

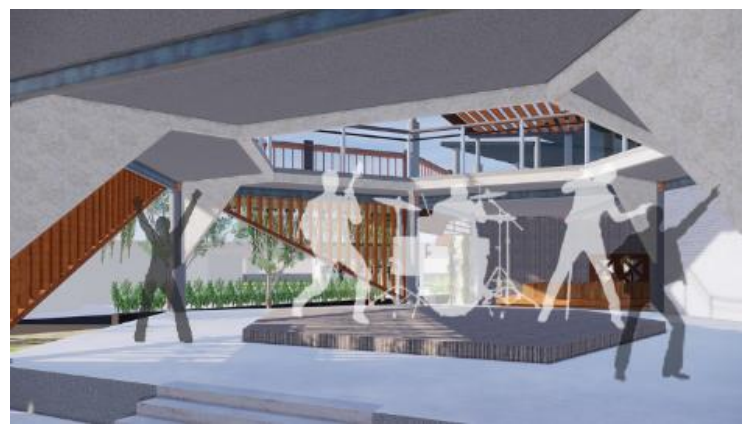

Gambar 13. Area Panggung Pentas

Sumber: Penulis, 2020

Area panggung yang ditujukan bagi para masyarakat serta anak-anak muda yang ingin tampil serta menunjukan bakat dan keterampilan mereka, misalnya anggota band, seni tari, dll.

c. Area Balai Warga

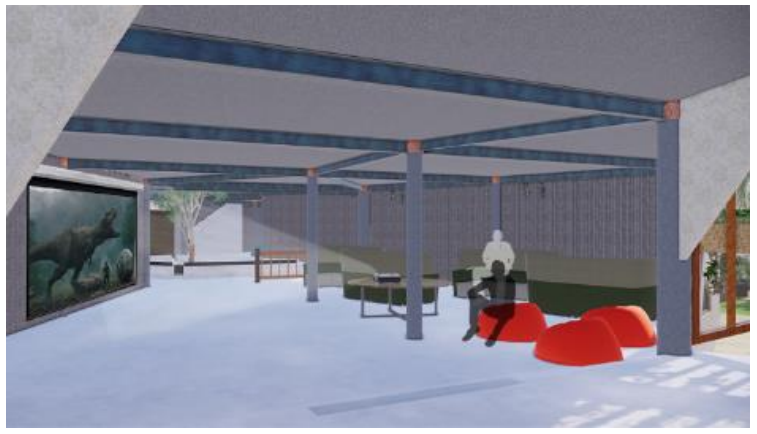

Gambar 14. Area Balai Warga

Sumber: Penulis, 2020

Dikarenakan minimnya fasilitas berkumpul bagi para masyarakat disekitar kawasan Semanan, maka dengan adanya fasilitas balai warga ini diharapkan dapat membantu meningkatkan interaksi antar warga. 


\section{d. Area Cooking Class}

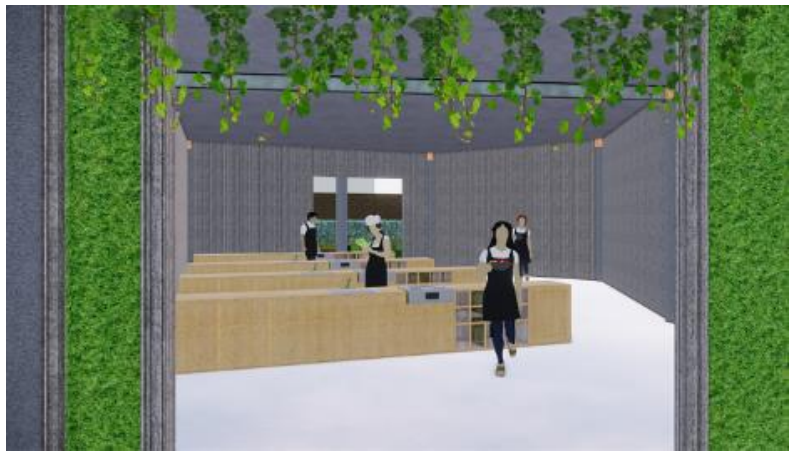

Gambar 15. Area Cooking Class

Sumber: Penulis, 2020

Merupakan area dimana para warga, diajarkan untuk menciptakan serta mengkreasikan makanan-makanan baru yang bisa diolah kemudian mereka jual sebagai salah satu dari program proyek yakni untuk mengembangkan sisi entrepreneurship dari para warga.

e. Open Market

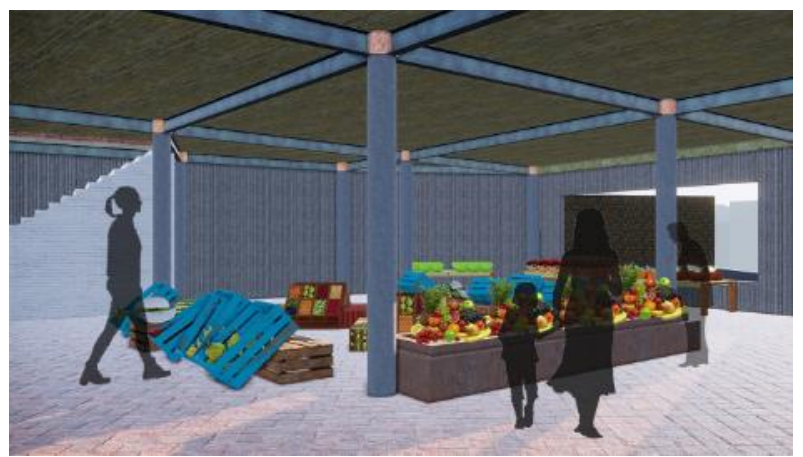

Gambar 16. Open Market

Sumber: Penulis, 2020

Merupakan hasil relokasi para pedagang buah yang berjualan pada tapak eksisting, namun dalam keadaan tidak teratur. Dari relokasi tersebut, para pedagang diatur pada zona agar lebih tertata.

\section{f. Area Roof Top}

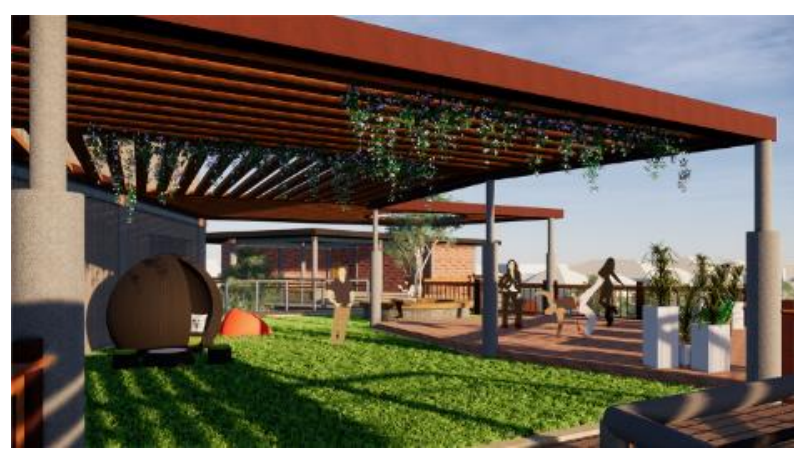

Gambar 17. Area Roof Top

Sumber: Penulis, 2020

Memberikan unsur rekreasi secara terbuka, serta taman-taman hijau, tidak hanya pada lantai dasar tetapi juga pada lantai 2 yang bisa digunakan sebagai wilayah bermain bagi anak-anak. 


\section{KESIMPULAN DAN SARAN \\ Kesimpulan}

Kehidupan di kawasan perkotaan dengan berbagai macam tekanan, baik dari tempat tinggal, tempat kerja maupun sekolah, membuat masyarakat memiliki tingkat kejenuhan yang lebih tinggi. Masyarakat ini membutuhkan sebuah ruang perantara antara tempat tinggal (first place) dan juga tempat kerja/ belajar (second place) yang berupa sebuah Third Place. Maka dari itu, muncul sebuah kebutuhan dari bentuk arsitektur yang berupa third place dengan Interaction untuk memfasilitasi kegiatan pengguna untuk bisa bercengkerama atau berbicara dengan satu sama lain, lalu Creative dan juga Expressive yang mana bertujuan untuk menyalurkan ide, kreativitas, serta minat bakat yang bisa digunakan untuk mengembangkan kemampuan dari pengguna. Kelurahan Semanan, Kalideres, merupakan sebuah lokasi dimana terdapat banyak aktivitas seperti area permukiman, area perbelanjaan dan juga kawasan industri. Dari keadaan dan potensi kawasan sekitar menjadikan Ruang Komunal-Informal ini menjadi sebuah third place yang strategis serta bisa mewadahi kebutuhan dari aktivitas masyarakat Kelurahan Semanan dan sekitarnya.

\section{Saran}

Proyek Informal Communal Space in Semanan, diharapkan dapat berguna dan memberi manfaat bagi lingkungan sekitar, terutama bagi para karyawan atau buruh yang secara garis besar paling terlihat keberadaannya di lingkungan sekitar tapak proyek. Lalu juga bagi masyarakat sekitar, maupun juga untuk generasi muda diharapkan dapat semakin tertarik untuk mengembangkan minat dan bakat mereka, baik dalam sisi kreativitas, usaha dan juga beragam social skills lainnya. Dalam merancang proyek ini perlu diperhatikan beberapa hal, seperti aksesibilitas, sirkulasi baik bagi kendaraan maupun pedestrian, lalu kebutuhan ruang dan program berdasarkan jenisnya. Yang mana hal-hal tersebut dapat mempengaruhi experience yang pengguna rasakan. Dalam laporan ini, penulis menyadari bahwa masih terdapat banyak kekurangan. Dan diharapkan adanya saran dan pendapat dari para pembaca, sehingga untuk proses perancangan kedepannya menjadi lebih baik.

\section{REFERENSI}

Anonim. (2019). Subsektor dalam industri kreatif Indonesia. Diakses 16 Februari 2020, dari https://ramakertamukti.wordpress.com/2009/01/09/14-subsektor-dalam-industri-kreatifindonesia/

Anwar, F. (2017). Ini Sebabnya Hidup di Perkotaan Rentan Memicu Stress. Diakses 15 Februari 2020, dari https://health.detik.com/berita-detikhealth/d-3473095/ini-sebabnya-hidup-diperkotaan-rentan-memicu-stres

Butler, S. M.; Diaz, C. (2016). "Third Places" as Community Builders". Retrieved February 16, 2020, from https://www.brookings.edu/blog/up-front/2016/09/14/third-places-ascommunity builders/

Darmiwati, R. (2000). Studi Ruang Bersama dalam Rumah Susun bagi Penghuni Berpenghasilan Rendah. DIMENSI (Jurnal Teknik Arsitektur), 28(2): Desember 2000.

Heimsath, C. (1998). Behavioral Architecture. US: McGraw-Hill.

Lang, J. (1987). Creating Architectural Theory; The Role of the Behavioural Sciences in Environmental Design. New York: Van Nostrand Reinhold Company.

Oldenburg, R. (1989). The Great Good Place. US: Paragon House.

Purwanto, E. W. (2007). Pola Ruang Komunal Di Rumah Susun Bandarharjo.

Tuan, Y. F. (1977). Space and Place: The Perspective of Experience. US: University of Minnesota Press. 
